\title{
Clinical Relevance of Circulating Tumour Cells in the Bone Marrow of Patients with SCCHN
}

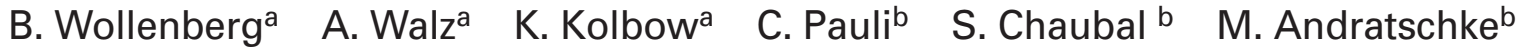 \\ ${ }^{a}$ Klinik und Poliklinik für Hals-Nasen-Ohren-Heilkunde,Universitätsklinikum Schleswig Holstein, Campus Lübeck, \\ ${ }^{\mathrm{b}}$ Klinik und Poliklinik für Hals-Nasen-Ohren-Heilkunde, Klinikum Großhadern Ludwig-Maximilians-Universität, München, Germany
}

\section{Key Words}

Micrometastases - SCCHN - Tumour marker .

Occult tumour cells $\cdot$ Minimal residual disease

\section{Summary}

Background: Clinical outcome of patients with head and neck squamous cell carcinoma (SCCHN) depends on several risk factors like the presence of locoregional lymph node or distant metastases, stage, localisation and histologic differentiation of the tumour. Circulating tumour cells in the bone marrow indicate a poor prognosis for patients with various kinds of malignoma. The present study examines the clinical relevance of occult tumour cells in patients suffering from SCCHN. Patients and Methods: Bone marrow aspirates of 176 patients suffering from SCCHN were obtained prior to surgery and stained for the presence of disseminated tumour cells. Antibodies for cytokeratin 19 were used for immunohistochemical detection with APAAP on cytospin slides. Within a clinical follow-up protocol over a period of 60 months, the prognostic relevance of several clinicopathological parameters and occult tumour cells was evaluated. Results: Single CK19-expressing tumour cells could be detected in the bone marrow of $30.7 \%$ of the patients. There is a significant correlation between occult tumour cells in the bone marrow and relapse. Uni- and multivariate analysis of all clinical data showed the metastases in the locoregional lymph system and detection of disseminated tumour cells in the bone marrow to be statistically highly significant for clinical prognosis. Conclusion: The detection of minimal residual disease underlines the understanding of SCCHN as a systemic disease. Further examination of such cells will lead to a better understanding of the tumour biology, as well as to improvement of diagnostic and therapeutic strategies.
Schlüsselwörter

Mikrometastasen - SCCHN - Tumormarker .

Okkulte Tumorzellen - Minimal residuale Tumorerkrankung

\section{Zusammenfassung}

Hintergrund: Der klinische Verlauf und die Prognose von Patienten mit Plattenepithelkarzinomen des Kopf-Hals-Bereiches (SCCHN) sind von vielen Risikofaktoren abhängig, wie dem Befall der lokoregionären Lymphabflusswege, Stadium, Lokalisation und Differenzierungsgrad des Primärtumors sowie dem Auftreten von Fernmetastasen. Die vorliegende Studie untersucht die klinische Relevanz der systemischen Verbreitung einzelner Tumorzellen im Knochenmark, die für eine Reihe von anderen Tumorentitäten als negativer Prognosefaktor beschrieben wurde, bei Patienten mit SCCHN. Patienten und Methoden: Nach schriftlichem Einverständnis wurden präoperativ Knochenmarksaspirate von 176 Patienten mit SCCHN entnommen und untersucht. Mittels monoklonaler Antikörper gegen Zytokeratin 19 (CK19) wurden die disseminierten Tumorzellen auf Zytospin Präparaten immunhistochemisch angefärbt. Mit Hilfe eines klinischen Nachsorgeprotokolls konnten die klinischen Daten während der folgenden 5 Jahre erhoben werden. Ergebnisse: Bei 30,7\% der Patienten mit SCCHN konnten einzelne CK19 exprimierende Tumorzellen im Knochenmark nachgewiesen werden. Es bestand eine signifikante Korrelation zwischen dem Nachweis CK19-positiver Zellen und einem Rezidiv. In einer uni- und multivariaten Analyse aller klinischen Daten erwies sich der Nachweis okkulter Tumorzellen im Knochenmark, sowie der Befall der lokoregionären Lymphknoten als signifikant für die klinische Prognose. Schlussfolgerungen: Die Daten der vorliegenden Studie beweisen eine systemische Verbreitung von Tumorzellen in den Blutkreislauf bei Patienten mit SCCHN mit erheblichem Einfluss auf den Verlauf der Erkrankung. Der Nachweis der minimal residualen Tumorerkrankung unterstreicht, dass Plattenepithelkarzinome des Kopf-Hals-Bereichs als systemische Erkrankung anzusehen sind. Die weitere Untersuchung solcher disseminierter Tumorzellen wird zu einem verbesserten Verständnis der Tumorbiologie und zu neuen diagnostischen sowie therapeutischen Möglichkeiten führen.

\begin{tabular}{ll}
\hline KARGER & ○ 2004 S. Karger GmbH, Freiburg \\
$\begin{array}{l}\text { Fax +49 76145207 14 } \\
\begin{array}{l}\text { E-mail Information@Karger.de } \\
\text { www.karger.com }\end{array}\end{array}$ & $\begin{array}{l}\text { Accessible online at: } \\
\text { www.karger.com/onk }\end{array}$
\end{tabular}

Prof. Dr. Barbara Wollenberg

Universitätsklinikum Schleswig Holstein Campus Lübeck

Ratzeburger Allee 160, D-23538 Lübeck

Tel. +49 451 500-2241, Fax -2249

E-mail Barbara.Wollenberg@hno.uni-luebeck.de 


\section{Introduction}

Patients suffering from squamous cell carcinoma of the head and neck (SCCHN) are at high risk to develop local recurrences or distant metastases. Depending on stage and localisation of the tumour, the risk for local relapse is higher than $50 \%$. The development of distant metastases of SCCHN occurs in $15-25 \%$ of the patients, although the true incidence might be even higher as described in several autopsy studies $[1,2]$. Early detection of disseminated tumour cells is tedious, because SCCHN metastasizes lymphogenously, implicating only a very low number of circulating tumour cells to be present in hematogenous compartments like peripheral blood and bone marrow [3].

The cytoskeleton of epithelial cells contains intermediatesized filaments which are composed of characteristic cytokeratins. Since neoplastic cells retain the main cytoskeletal properties of their progenitors, cytokeratins are found in normal as well as in malignant epithelia [4]. Here we examine cytokeratin 19 (CK19), which is expressed in most simple epithelia, in cultured keratinocytes and in normal and malignant squamous epithelia, for the detection of disseminated tumour cells in bone marrow of patients. Expression of cytokeratins is restricted to epithelial cells, which, in healthy persons, are absent from hematogenous compartments like peripheral blood or bone marrow. The detection of CK19 in peripheral blood and bone marrow of patients suffering from epithelial malignoma may therefore indicate the unphysiological presence of epithelial cells, which might be caused by the spread of the respective malignoma. As CK19-expressing cells are lacking in the bone marrow of healthy donors, these cells are highly likely to represent disseminated tumour cells. Therefore, we chose the bone marrow, an exclusively mesenchymal organ which represents a defined medium for the detection of single circulating cancer cells, for the diagnosis of disseminated disease in patients suffering from SCCHN.

The aim of the study was to evaluate the prognostic significance of CK19-expressing tumour cells in bone marrow for clinical outcome of patients with SCCHN. Our approach may help to detect a new prognostic marker to select those patients who are at high risk to develop local or distant recurrence. By the application of adjuvant systemic and multimodal therapies, as well as by carrying out further examinations it might be possible to improve the prognosis for those patients.

\section{Patients and Methods}

\section{Patients}

Patients with histologically defined SCCHN of various sites $(\mathrm{n}=176)$ were recruited and followed for 60 months. Tumour stage and grading were determined according to the TNM classification [5]. All patients underwent surgery for removal of the tumour. Patients with higher tumour stages received subsequent radiotherapy. During follow-up, patients initially were investigated every 3 months and after 1 year every 6 months.
Clinical observation included physiological examination, chest X-ray, endoscopy, ultrasound, routine bone scintigraphy and CT scan in cases of specific suspect. In the grading, disease-free survival was defined as survival without recurrence or distant metastases or second primary cancer. 5 -year survival rates were analysed in all patients.

Bone Marrow Aspirates, Preparation and Immunohistological Investigation

After written informed consent, bone marrow aspirates from patients with SCCHN were taken prior to surgery from both iliac crests in heparincoated syringes. In order to avoid displacement of epidermal cells into the sample, aspiration was performed through a small cut in the skin. Aspirates were separated through Ficoll/Hypaque density centrifugation according to standard protocol [6]. Cytospin preparations were prepared with $5 \times 10^{5}$ cells per glass slide. From each patient $2 \times 10^{6}$ nucleated cells were examined.

CK19 expression was detected immunohistochemically by the APAAP method [7], using the monoclonal KS 19.1 antibody (Progen, Heidelberg, Germany) against CK19, at a concentration of $5 \mu \mathrm{g} / \mathrm{ml}$. Specifically bound antibody was visualised by staining with newfuchsin $(5 \%$ in $2 \mathrm{~N} \mathrm{HCl})$. Cellnuclei were counterstained with hemalaun (Merck, Darmstadt, Germany). Endogenous alkaline phosphatase activity was blocked by incubation with levamisole. Bone marrow samples were classified CK19 positive if one or more cells clearly stained red could be identified. Bone marrow samples of healthy donors served as negative controls, whereas FaDu cells (pharyngeal squamous cell carcinoma, ATCC, Rockville, MD, USA) served as positive controls. For isotype control two slides of each patient and normal volunteer were incubated with mAb IgG2aא (No. M-9411, Sigma Immunochemicals, Deisenhofen, Germany) in an appropriate concentration.

\section{Statistical Analysis}

The chi-square test was employed to evaluate correlations between the presence of CK19-positive cells in bone marrow and relapse as well as the clinicopathological parameters. Cox proportional hazards model [8] was applied for uni- and multivariate analysis, using the program BMDP2L. The Kaplan-Meier method [9] was used to determine survival rates. Statistical significance was calculated with the use of the log-rank test and denoted by $\mathrm{p}$ values lower than 0.02 .

\section{Results}

\section{CK19-Expressing Tumour Cells in Patients' Bone Marrow Samples and Clinical Parameters}

In 54 of 176 bone marrow samples $(30.7 \%)$ of patients with SCCHN of various sites, CK19-expressing tumour cells could be detected. Bone marrow samples of all healthy volunteers and all isotype controls showed no CK19 expression. The detection of occult tumour cells increased with the size of the primary tumour and with advanced lymph node involvement resulting in higher UICC stages. Histological grading and localisation did not influence the incidence of tumour cells. Statistically, there was no difference between patients with or without tumour cells in the bone marrow within the basic clinical parameters (table 1).

\section{CK19-Expressing Tumour Cells in Bone Marrow and Tumour Recurrence}

Applying a clinical follow-up protocol, 176 patients were followed over a period of 5 years, which is the critical threshold 
Table 1. Correlation of clinical parameters with the presence of CK19-expressing tumour cells in the bone marrow

\begin{tabular}{|c|c|c|c|c|c|c|}
\hline \multirow[t]{2}{*}{ Parameter } & \multirow[t]{2}{*}{ All patients, $\mathrm{n}$} & \multicolumn{2}{|c|}{$\mathrm{CK} 19^{+}$patients } & \multicolumn{2}{|c|}{$\mathrm{CK} 9^{-}$patients } & \multirow[t]{2}{*}{$\mathrm{p}$ Value } \\
\hline & & $\mathrm{n}$ & $\%$ & $\mathrm{n}$ & $\%$ & \\
\hline \multicolumn{7}{|l|}{ UICC-stage } \\
\hline $\mathrm{UICC} 1 / 2$ & 60 & 15 & 25.00 & 45 & 75.00 & \multirow{2}{*}{0.240} \\
\hline UICC3/4 & 116 & 39 & 33.62 & 77 & 66.38 & \\
\hline \multicolumn{7}{|l|}{ Tumor extension } \\
\hline pT1 & 44 & 10 & 22.73 & 34 & 77.27 & \multirow{4}{*}{0.595} \\
\hline pT2 & 60 & 19 & 31.67 & 41 & 68.33 & \\
\hline pT3 & 43 & 15 & 34.88 & 28 & 65.12 & \\
\hline pT4 & 29 & 10 & 34.48 & 19 & 65.52 & \\
\hline \multicolumn{7}{|l|}{$\begin{array}{l}\text { Lymph node } \\
\text { involvement }\end{array}$} \\
\hline pN0 & 88 & 27 & 30.68 & 61 & 69.32 & \multirow{4}{*}{0.831} \\
\hline pN1 & 31 & 8 & 25.81 & 23 & 74.19 & \\
\hline $\mathrm{pN} 2$ & 50 & 16 & 32.00 & 34 & 68.00 & \\
\hline $\mathrm{pN} 3$ & 7 & 3 & 42.86 & 4 & 57.14 & \\
\hline \multicolumn{7}{|l|}{ Localisation } \\
\hline Oral cavity & 37 & 10 & 27.03 & 27 & 72.97 & \multirow{4}{*}{0.610} \\
\hline Oropharynx & 43 & 11 & 25.58 & 32 & 74.42 & \\
\hline Larynx & 68 & 22 & 32.35 & 46 & 67.65 & \\
\hline Hypopharynx & 28 & 11 & 39.29 & 17 & 60.71 & \\
\hline \multicolumn{7}{|l|}{ Grading } \\
\hline G0 & 7 & 2 & 28.57 & 5 & 71.43 & \multirow{4}{*}{0.739} \\
\hline G1 & 94 & 31 & 32.98 & 63 & 67.02 & \\
\hline G2 & 73 & 21 & 28.77 & 52 & 71.23 & \\
\hline G3 & 2 & 0 & & 2 & 100.00 & \\
\hline
\end{tabular}

for survival in SCCHN. During the follow-up time 60 patients (34.09\%) developed recurrent disease: 34 patients $(56.67 \%)$ developed locoregional recurrences and 26 (43.33\%) presented with distant metastases. The presence of occult tumour cells in the bone marrow was tightly associated with recurrent disease. $50 \%(27 / 54)$ of patients with CK19-positive cells in the bone marrow relapsed (locoregional or distant (combined recurrence noted under distant metastases)) compared to only $27.05 \%$ (33/122) without. Statistical evaluation lead to a significant correlation with $\mathrm{p}=0.003$.

\section{Prognostic Relevance of Clinicopathological Parameters and CK19-Expressing Tumour Cells in the Bone Marrow}

Applying a multivariate or univariate analysis of clinical parameters and the presence of occult tumour cells in the bone marrow the prognostic relevance for overall survival was most significantly affected by lymph node involvement $(\mathrm{p}=0.0001)$ and the presence of CK19-expressing, disseminated tumour cells in the bone marrow $(\mathrm{p}=0.0066)$ (table 2$)$.

Univariate consideration identified lymph node involvement ( $p=0.0001)$, CK19 positivity of the bone marrow $(\mathrm{p}=0.0124)$ and late UICC stages of disease $(\mathrm{p}=0.0173)$ as significant risk factors in SCCHN, whereas no relevance could be detected for the tumour size $(p=0.1033)$ and differentiation of the tumour $(\mathrm{p}=0.2243)($ table 3$)$.

\section{Discussion}

Over the last decade, circulating tumour cells in the bone marrow have gained increasing prognostic relevance in various kinds of solid malignoma. Many studies have demonstrated a significant correlation between the presence of disseminated tumour cells in secondary organs, such as the bone marrow, peripheral blood or lymph nodes and a high risk for local relapse, distant metastases and a shortened overall survival in patients with breast and colorectal cancer [10-12]. Furthermore, it has been shown that detection of those cells with immunohistochemical and molecular techniques is feasible [13-16].

The aim of the present study was to examine the prognostic significance of circulating tumour cells present in the bone marrow of patients with SCCHN. In a comparison of all standard clinical data with the presence of occult tumour cells, significant parameters should be established to distinguish those patients with a high risk to develop local or distant relapse.

In the present study monoclonal antibodies directed against CK19 were applied for the diagnosis of occult carcinoma cells. CK19-expressing tumour cells were detectable in the bone marrow of $30.68 \%$ of patients; $50 \%$ of these patients relapsed, compared with only $27.05 \%$ without CK19-positive cells in the bone marrow. Further, statistical evaluation led to a signifi- 
cant correlation between CK19 positivity of the bone marrow and the incidence of relapse $(\mathrm{p}=0.003)$. These results indicate that patients with CK19-positive bone marrow have a higher risk for the development of recurrent disease than those patients with CK19-negative bone marrow. In a univariate and multivariate statistical analysis the detection of occult tumour cells in the bone marrow showed to be statistically as valid as locoregional metastases for the prediction of clinical outcome of the disease. Tumour spread to the locoregional lymph nodes is the most significant risk factor, in univariate $(\mathrm{p}=0.0001)$ as well as multivariate $(\mathrm{p}=0.0001)$ analysis. Further, the presence of occult tumour cells in the bone marrow was found to be relevant as an univariate $(\mathrm{p}=0.0124)$ and multivariate $(\mathrm{p}=0.0066)$ parameter whereas UICC stage of the disease ( $p=0.0173)$ appeared to be significant only in univariate analysis.

SCCHN metastasize in lymphogenous ways, frequently using clinically undiscovered, complex pathways of the locoregional lymphatic vessels [17]. Distant metastases frequently occur in lung, liver and skeleton in $15-25 \%$ of the patients following first therapy. To date, the true incidence of distant metastases remains unclear as autopsy studies report an incidence of $40-57 \%[18,19]$. The minimal residual disease of occult tumour cells remaining in locoregional lymphatic vessels or distant organ systems poses the major problem and documents that SCCHN is a systemic disease.

Expecting ubiquitous spread of occult tumour cells, the peripheral blood should be very suitable for the detection of such cells. However, although detection methods have been improved very much over the years, the use of occult tumour cells in the blood as surrogate marker for validation of new therapeutic strategies is limited. Due to different spreading kinetics and the diluting effect of the total blood volume, capturing an adequate amount of tumour cells in a small blood sample is difficult and probably does not reflect the true situation. The bone marrow is easily accessible and thought to function as an extra filter for occult tumour cells, although bone metastases are rare in SCCHN. In this study we performed bone marrow aspiration from patients both iliac crests. This seems quite suitable, since in adults the highest coherent amount of active haematopoietic bone marrow (one third) is located in the pelvis and examination of bone marrow aspirates derived from the iliac crests gives view to a large proportion of the whole bone marrow. However, as shown in the literature the detection rate of disseminated tumour cells increases proportionally with the increase of bone marrow aspiration sites. In future, use of a larger number of puncture sites might improve the detection rate of tumour cells in patients' bone marrow [20]. Earlier publications document that as few as 1-3 tumour cells in a million bone marrow cells can be detected in patients with SCCHN [21-23].

The techniques for the detection of micrometastatic cells cover different methods and vary in their sensitivity and the specificity of the marker used. Several groups already demon-
Table 2. Correlation between relapse, metastases and CK19-expressing tumour cells in the bone marrow

\begin{tabular}{|c|c|c|c|c|c|}
\hline & \multirow[t]{2}{*}{ Total, $\mathrm{n}$} & \multicolumn{2}{|c|}{ Relapse } & \multicolumn{2}{|c|}{ Metastases } \\
\hline & & $\mathrm{n}$ & $\%$ & $\mathrm{n}$ & $\%$ \\
\hline CK $19^{+}$Patients & 54 & 27 & 50 & 13 & 24.07 \\
\hline CK19- Patients & 122 & 33 & 27.05 & 14 & 11.48 \\
\hline $\mathrm{p}$ Value & & 0.003 & & 0.032 & \\
\hline
\end{tabular}

Table 3. Prognostic relevance of clinicopathological parameters and CK19-expressing tumour cells in the bone marrow - univariate and multivariate consideration

\begin{tabular}{lll}
\hline Parameter & $\begin{array}{l}\text { Univariate } \\
\text { analysis, } \mathrm{p}\end{array}$ & $\begin{array}{l}\text { Multivariate } \\
\text { analysis, } \mathrm{p}\end{array}$ \\
\hline Lymph node state & 0.0001 & 0.0001 \\
CK19-positive bone marrow & 0.0124 & 0.0066 \\
UICC stage of disease & 0.0173 & 0.2863 \\
Tumour size & 0.1033 & 0.1483 \\
$\begin{array}{l}\text { Histological differentiation } \\
\text { of the tumour }\end{array}$ & 0.2243 & 0.9243 \\
\hline
\end{tabular}

strated that the use of cytokeratins as markers for disseminated disease in the bone marrow is associated with difficulties, which on the one hand depends on the technique applied for detection, on the other hand on the species of cancer and the cytokeratin investigated [24].

Immunohistochemistry is most widespread in the diagnosis of occult carcinoma cells, since it allows visualisation of the detected cells. However, immunohistochemical examination of bone marrow samples sometimes might be affected by cross reactions between the antibodies and Fc receptors expressed on progenitor cells or immunocytes like macrophages, which are present in the bone marrow and which might cause false positive results. Control stains of healthy bone marrow donors are necessary to safely set up the technique.

Through applying molecular methods like RT-PCR (reverse transcriptase polymerase chain reaction) sensitivity of immunohistochemical detection can be raised. Theoretically this method offers the possibility to detect single RNA molecules, so that it seems especially suitable to detect very low numbers of cells [25]. On the other hand, such a high sensitivity may also detect low illegitimate or ectopic expression levels of some molecules and thereby may cause false positive results [26-28]. Using CK19 as marker for RT-PCR-based detection of occult tumour cells in the bone marrow of cancer patients, one also has to be aware of the known existence of pseudogenes as well as of low levels of CK19 expressed by stromal cells which are present in the bone marrow.

Further studies will cover examination of biological behaviour of occult tumour cells. Characterising migratory behaviour, 
phenotypic and growth characteristics as well as expansion of circulating human tumour cells may widen the possibilities for a morphological and genetic characterisation of disseminated disease in SCCHN and thus lead to new immunotherapeutic strategies [28, 29].

\section{Acknowledgements}

We thank Bärbel Schmitt for excellent technical assistance. This study was supported by institutional grants and the Deutsche Forschungsgesellschaft (Wo 483/1-2 to B. W.)

\section{References}

1 Zbaren P, Lehmann W: Frequency and sites of distant metastases in head and neck squamous cell carcinoma. An analysis of 101 cases at autopsy. Arch Otolaryngol Head Neck Surg 1987;113:762764.

2 Slootweg PJ, Bolle CW, Koole R, Hordijk GJ Cause of death in squamous cell carcinoma of the head and neck. An autopsy study on 31 patients. J Craniomaxillofac Surg 1992;20:225-227.

3 Mayer B, Funke I, Johnson JP: High expression of a Lewis(x)-related epitope in gastric carcinomas indicates metastatic potential and poor prognosis. Gastroenterology 1996;111:1433-1446.

4 Burchill SA, Bradbury MF, Pittman K, Southgate J, Smith B, Selby P: Detection of epithelial cancer cells in peripheral blood by reverse transcriptasepolymerase chain reaction. Br J Cancer 1995;71: 278-281.

5 Hermanek P, Scheibe O, Spiessl B, Wagner G: TNM classification of malignant tumors: The new 1987 edition. Röntgenbl 1987;40:200.

6 Loos JA, Roos D: Ficoll-isopaque gradients for the determination of density distributions of human blood lymphocytes and other reticulo-endothelial cells. Exp Cell Res 1974;86:333-341.

7 Cordell JL, Falini B, Erber WN, Ghosh AK, Abdulaziz Z, MacDonald S, Pulford KA, Stein H, Mason DY: Immunoenzymatic labeling of monoclonal antibodies using immune complexes of alkaline phosphatase and monoclonal anti-alkaline phosphatase (APAAP complexes). J Histochem Cytochem 1984; 32:219-229.

8 Cox DR: Regression models and life tables. J Stat Soc (B) 1972;34:187-220.

9 Kaplan EL, Meier P: Nonparametric estimation from incomplete observation. J Am Stat Assoc 1958;53:457-481.

10 Mansi JL, Easton D, Berger U, Gazet JC, Ford HT, Dearnaley D, Coombes RC: Bone marrow micrometastases in primary breast cancer: Prognostic significance after 6 years' follow-up. Eur J Cancer 1991;27:1552-1555.

11 Cote RJ, Rosen PP, Lesser ML, Old LJ, Osborne MP: Prediction of early relapse in patients with operable breast cancer by detection of occult bone marrow micrometastases. J Clin Oncol 1991;9: 1749-1756.
12 Lindemann F, Schlimok G, Dirschedl P, Witte J, Riethmuller G: Prognostic significance of micrometastatic tumour cells in bone marrow of colorectal cancer patients. Lancet 1992;340:685-689.

13 Riesenberg R, Oberneder R, Kriegmair M, Epp M, Bitzer U, Hofstetter A, Braun S, Riethmuller G, Pantel K: Immunocytochemical double staining of cytokeratin and prostate specific antigen in individual prostatic tumour cells. Histochemistry 1993;99: 61-66.

14 Deguchi T, Doi T, Ehara H, Ito S, Takahashi Y, Nishino Y, Fujihiro S, Kawamura T, Komeda H, Horie M: Detection of micrometastatic prostate cancer cells in lymph nodes by reverse transcriptase-polymerase chain reaction. Cancer Res 1993;53:53505354.

15 Moul JW, Lewis DJ, Ross AA, Kahn DG, Ho CK, McLeod DG: Immunohistologic detection of prostate cancer pelvic lymph node micrometastases: Correlation to preoperative serum prostatespecific antigen. Urology 1994;43:68-73.

16 Pelkey TJ, Frierson HF Jr., Bruns DE: Molecular and immunological detection of circulating tumor cells and micrometastases from solid tumors. Clin Chem 1996;42:1369-1381.

17 Werner JA, Dunne AA, Myers JN: Functional anatomy of the lymphatic drainage system of the upper aerodigestive tract and its role in metastases of squamous cell carcinoma. Head Neck 2003;25:322332.

18 Ervin TJ, Clark JR, Weichselbaum RR, Fallon BG, Miller D, Fabian RL, Posner MR, Norris CM Jr., Tuttle SA, Schoenfeld DA: An analysis of induction and adjuvant chemotherapy in the multidisciplinary treatment of squamous-cell carcinoma of the head and neck. J Clin Oncol 1987:5:10-20.

19 Vokes EE, Weichselbaum RR, Lippman SM, Hong WK: Head and neck cancer. N Engl J Med 1993; 328:184-194.

20 Schlimok G, Funke I, Pantel K, Strobel F, Lindemann F, Witte J, Riethmuller G: Micrometastatic tumour cells in bone marrow of patients with gastric cancer: Methodological aspects of detection and prognostic significance. Eur J Cancer 1991;27: 1461-1465.
21 Wollenberg B, Ollesch A, Maag K, Funke I, Wilmes E: Micrometastases in bone marrow of patients with cancers in the head and neck area. Laryngorhinootologie 1994;73:88-93.

22 Gath HJ, Heissler E, Hell B, Bier J, Riethmuller G, Pantel K: Immunocytologic detection of isolated tumor cells in bone marrow of patients with squamous cell carcinomas of the head and neck region. Int J Oral Maxillofac Surg 1995;24:351-355.

23 Gath HJ, Brakenhoff RH: Minimal residual disease in head and neck cancer. Cancer Metastases Rev 1999;18:109-126.

24 Pantel K, Schlimok G, Angstwurm M, Weckermann D, Schmaus W, Gath H, Passlick B, Izbicki JR, Riethmuller G: Methodological analysis of immunocytochemical screening for disseminated epithelial tumor cells in bone marrow. J Hematother 1994;3:165-173.

25 Partridge M, Brakenhoff R, Philips E, Ali K, Francis R, Hooper R, Lavery K, Brown A, Langdon: Detection of rare disseminated tumor cells identifies head and neck cancer patients at risk of treatment failure. J Clin Cancer Res 2003;9:5287-5294.

26 De Graaf H, Maelandsmo GM, Ruud P, Forus A, Oyjord T, Fodstad O, Hovig E: Ectopic expression of target genes may represent an inherent limitation of RT-PCR assays used for micrometastases detection: Studies on the epithelial glycoprotein gene EGP-2. Int J Cancer 1997;72:191-196.

27 Zippelius A, Pantel K: RT-PCR-based detection of occult disseminated tumor cells in peripheral blood and bone marrow of patients with solid tumors. An overview. Ann N Y Acad Sci 2000;906:110-123.

28 Chaubal S, Wollenberg B, Kastenbauer E, Zeidler R: Ep-CAM-a marker for the detection of disseminated tumor cells in patients suffering from SCCHN. Anticancer Res 1999;19(3B):2237-2242.

29 Andratschke M, Pauli C, Stein M, Chaubal S, Wollenberg B: MHC-class I antigen expression on micrometastases in bone marrow of patients with head and neck squamous cell cancer. Anticancer Res 2003;23(2B):1467-1471. 